\title{
Elbow your way into reporting paediatric elbow fractures - A simple approach
}

\author{
Authors: \\ Tracy Kilborn ${ }^{1}$ \\ Halvani Moodley ${ }^{1}$ \\ Stewart Mears ${ }^{1}$ \\ Affiliations: \\ ${ }^{1}$ Red Cross War Memorial \\ Children's Hospital, \\ Cape Town, South Africa \\ Correspondence to: \\ Tracy Kilborn \\ Email: \\ tracykilborn@gmail.com \\ Postal address: \\ Red Cross War Memorial \\ Children's Hospital, \\ Klipfontein Road, Cape Town \\ 7700, South Africa \\ Dates: \\ Received: 02 June 2015 \\ Accepted: 11 Aug. 2015 \\ Published: 18 Dec. 2015 \\ How to cite this article: \\ Kilborn T, Moodley, $\mathrm{H}$, \\ Mears, S. Elbow your way \\ into reporting paediatric \\ elbow fractures - A simple \\ approach. S Afr J Rad. \\ 2015;19(2): Art. \#881, \\ 10 pages. http://dx.doi.org/ \\ 10.4102/sajr.v19i2.881

\section{Copyright:} \\ (C) 2015. The Authors. \\ Licensee: AOSIS \\ OpenJournals. This work is \\ licensed under the Creative \\ Commons Attribution \\ License.
}

Read online:

Scan this QR

code with your

smart phone or

mobile device

to read online.
The evaluation of X-rays of the paediatric elbow in the setting of trauma is challenging. The difficulty arises from the complex developmental anatomy of the elbow, with its multiple ossification centres and the differences in the pattern of injuries between adults and children.

It is essential to evaluate the radiographs systematically. This review will provide an overview of the developmental anatomy, the range of soft tissue and skeletal findings, and demonstrate tips and pitfalls in radiographic interpretation in paediatric elbow trauma.

\section{Introduction}

Paediatric elbow trauma is common. Radiographic diagnosis of the various fracture types is critical due to the overlapping clinical presentations and to avoid misdiagnosis that can result in growth disturbances. A systematic approach to reporting, supported by an understanding of the age-dependent variation in developmental anatomy of the elbow, is indispensable to the radiologist in tackling these challenging injuries.

We now discuss a practical and simple guide to post-traumatic paediatric elbow radiographic reporting.

\section{A systematic approach to reporting Reporting checklist ${ }^{1}$}

1. Technically adequate film (AP and lateral).

2. Soft tissue swelling and joint effusion (fat pads).

3. Alignment - anterior humeral and radiocapitellar lines.

4. Ossification centres (CRITOL).

5. Visible fracture of distal humerus.

6. Visible fracture of radius or ulna.

7. No visible fracture but positive fat pad - follow up in 7-10 days.

\section{Step 1 - Evaluate radiographic technique}

Initial radiographic interpretation consists of the anteroposterior (AP) and lateral projections.

The AP should be performed with the elbow in full extension and the forearm supinated (Figure 1). For the true lateral projection, the elbow should be flexed 90 degrees with the forearm supinated (Figure 2). The cassette should be centred on the elbow joint with its long axis parallel to the forearm. In an optimal lateral projection, the posterior supracondylar ridges of the humerus are superimposed and the olecranon process is viewed in profile (Figure 3). Radiographic landmarks are unreliable and significant pathology can be obscured in a suboptimal lateral projection. The internal oblique view is useful in the demonstration of lateral condyle fractures and in assessing the degree of displacement. ${ }^{2}$

The routine use of comparative views is not recommended as it comes at a considerable cost of radiation exposure to the child. ${ }^{3}$ In addition, several studies have shown that the routine use of comparative views was a predominant choice of inexperienced clinicians, did not alter patient management in the majority of cases and therefore could not be justified. . $, 5,6,7^{2}$

\section{Step 2 - Look for soft tissue swelling and joint effusion}

Localised soft tissue swelling either over the medial or the lateral aspects of the elbow should raise suspicion of a medial epicondylar or lateral condylar fracture.

The elbow fat pads are situated external to the synovium. On a true lateral radiograph with 90 degrees of flexion the normal anterior fat pad is within the coronoid fossa and is seen as a radiolucent line parallel to the anterior humeral cortex; the posterior fat pad is pressed deep into the olecranon fossa by the triceps tendon and the anconeus muscle and is invisible. ${ }^{8}$ Distention 


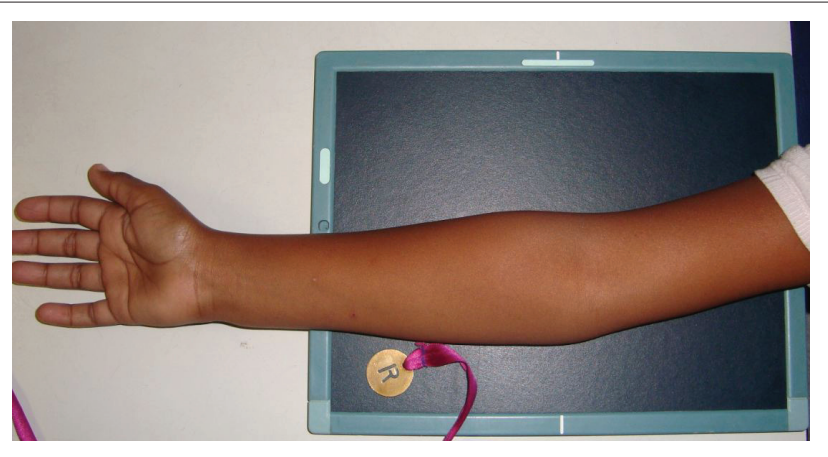

FIGURE 1: Positioning for the anteroposterior (AP) projection. The elbow should be in contact with and in the middle of the cassette in full extension with the forearm supinated.

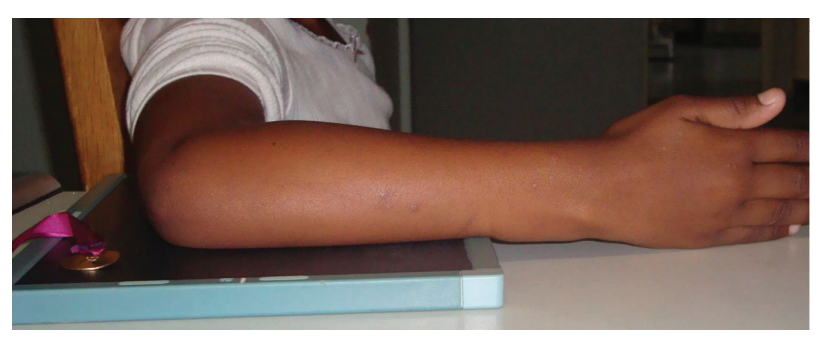

FIGURE 2: Positioning for the lateral projection. The elbow should be flexed at 90 degrees with the forearm supinated and thumb superior

of a structurally intact joint causes displacement of the fat pads - the posterior fat pad moves posterior and superior and becomes visible; the anterior fat pad becomes more sail-like (Figure 3). A false negative fat pad sign may occur in poor positioning, in capsular rupture or in the setting of significant extracapsular abnormality. ${ }^{8}$ Approximately $70 \%-$ $90 \%$ of children with an elbow effusion will have a visible fracture; however, there is wide debate in the literature about the presence of radiographically occult fractures in the setting of a joint effusion at presentation - radiographic follow-up by Donnelly et al reported $54 \%$ of patients showing healing fractures. ${ }^{9}$ More recent studies looking at MRI and MDCT show occult fractures in the majority of patients, although
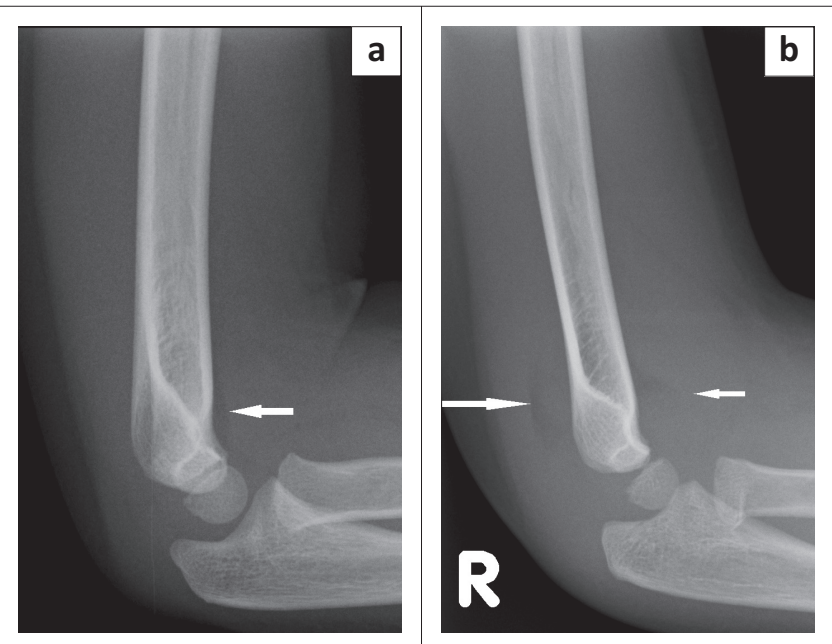

FIGURE 3: (a) Good quality lateral projection with the posterior supracondylar ridges superimposed and olecranon in profile. Note the normal anterior fat pad lying parallel to the anterior humeral shaft (arrow). (b) Lateral projection in patient with radial neck fracture showing a posterior fat pad (long arrow) and displaced anterior fat pad (short arrow). they do stress that these investigations did not significantly alter management. ${ }^{10,11}$. The standard protocol for suspected occult fractures in most institutions remains posterior elbow splinting with follow-up radiographs at 7-10 days.

\section{Step 3 - Evaluate alignment}

The anterior humeral and radio-capitellar lines should be used to gauge elbow alignment.

The anterior humeral line is drawn along the anterior cortex of the humerus and should bisect the middle third of the capitellum. Since the line evaluates the relative positions of two parts of the same bone, malalignment indicates a fracture - in most cases, posterior displacement of the capitellum in a supracondylar fracture. This sign relies on adequate ossification of the capitellum and therefore is reliable in children over the age of 4 years only. ${ }^{12}$ In younger children when the capitellar ossification centre is still small, the anterior humeral line may not pass through the ossified portion (Figure 4).

The radiocapitellar line evaluates the relationship of the proximal radius to the capitellum on all views. If the integrity of this line is compromised, then dislocation should be suspected (Figure 5).

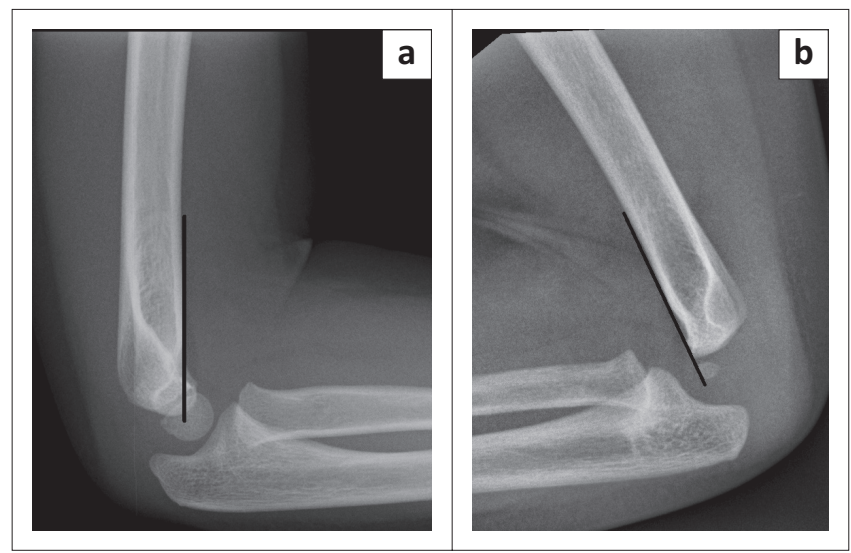

FIGURE 4: (a) Normal anterior humeral line in a 4 year old passes through the middle third of the capitellum (black line). (b) Anterior humeral line in a 6 month old child with will not pass through the middle third of the partially ossified capitellum (black line).

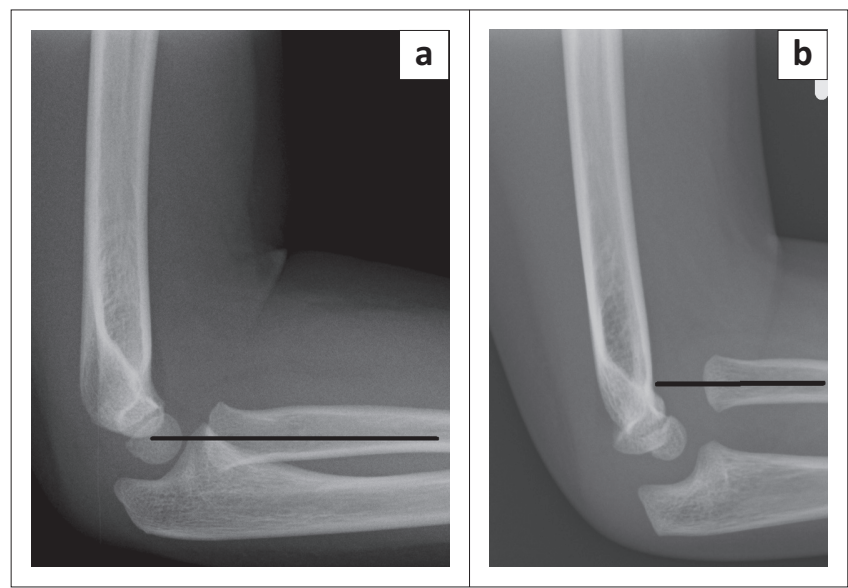

FIGURE 5: (a) Normal radiocapitellar line (black line). (b) Displaced radiocapitellar line that does not intersect the capitellum in radial dislocation (black line). 


\section{Step 4 - Identify ossification centres}

Although ossification of the elbow is complex, this knowledge is essential to all practitioners involved in the evaluation of paediatric trauma. The ossification appears earlier in girls than in boys and there is wide variation between individuals of the same sex. In boys, with the exception of the capitellum, an average delay of two years is seen when compared to girls and there are also differences between population groups. ${ }^{13,14,15}$ The sequence of appearance of the six centres of secondary ossification is mostly predictable (Table 1) and is best remembered by using the acronym CRITOL (Figure 6).

TABLE 1: Ossification centres. ${ }^{13,14,15}$

\begin{tabular}{|c|c|c|c|}
\hline $\begin{array}{l}\text { Ossification } \\
\text { centre }\end{array}$ & $\begin{array}{c}\text { Average age girls } \\
\text { (range) }\end{array}$ & $\begin{array}{l}\text { Average age boys } \\
\text { (range) }\end{array}$ & Appearance \\
\hline Capitellum & 3-12 months & 3-12 months & Single smooth centre \\
\hline Radial & 5 y $(1.6-6.8$ y) & 5 y $(3.3-8.5 y)$ & Oval then flattened \\
\hline $\begin{array}{l}\text { Internal (medial) } \\
\text { epicondyle }\end{array}$ & 5 y $(1.3-7.1$ y) & $7 y(3.9-9.7 y)$ & Single \\
\hline Trochlea & 9 y $(6-11$ y) & 10.5 y $(7-12.5$ y) & $\begin{array}{l}\text { Two or more, } \\
\text { fragmented and can } \\
\text { project into joint }\end{array}$ \\
\hline Olecranon & 9 y $(6-10.6 y)$ & 11 y $(7.6-12.2$ y) & $\begin{array}{l}\text { Bipartite, irregular and } \\
\text { sclerotic }\end{array}$ \\
\hline Lateral epicondyle & 10 y (7.3-11 y) & 12 y $(8-14$ y) & Single or multiple \\
\hline
\end{tabular}

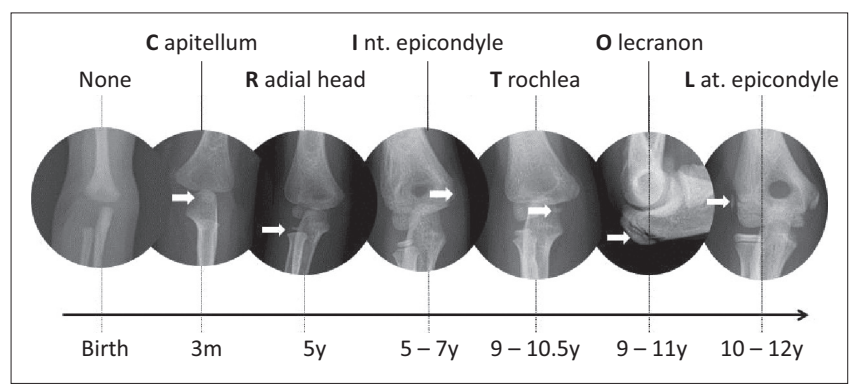

FIGURE 6: Timeline of the appearance of ossification centres.
It should be noted that there are no specific reference data about the timing and sequence of ossification in South African children, and a previous study showed differences in the sequence of ossification in Chinese children when compared to the reported standards. ${ }^{14}$

\section{Step 5 - Look for distal humeral fractures a) Supracondylar fracture $(50 \%-70 \%)$ (Diagram 1$)$}

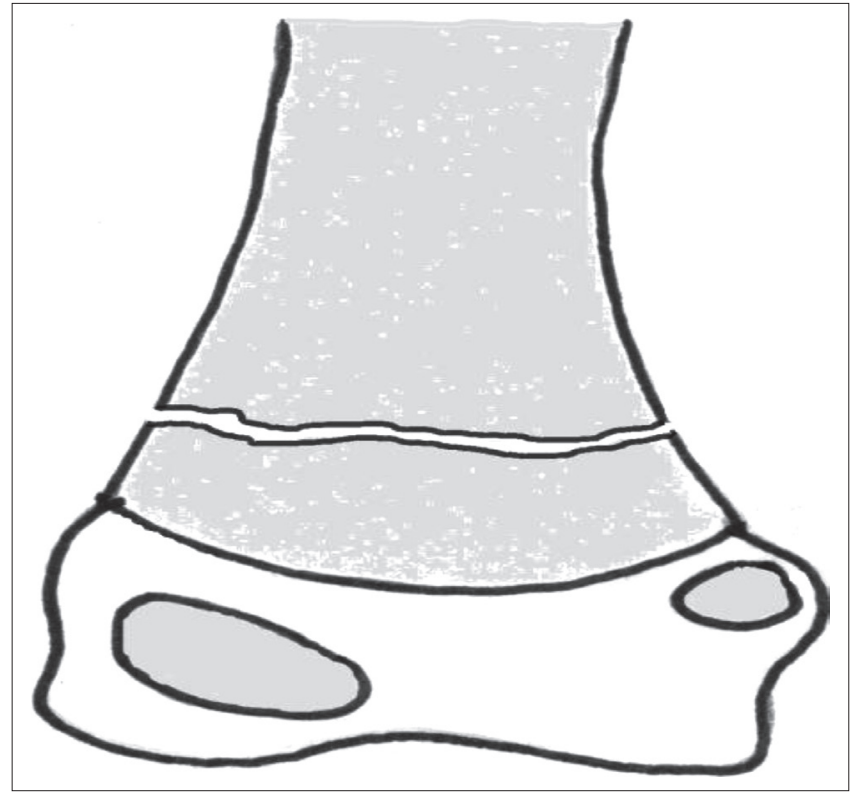

DIAGRAM 1

- T!PS

- Lateral view most helpful - look for posterior fat pad.

- Anterior humeral line abnormal in 94\% cases (Figure 7).

- Baumann's angle predicts varus deformity.
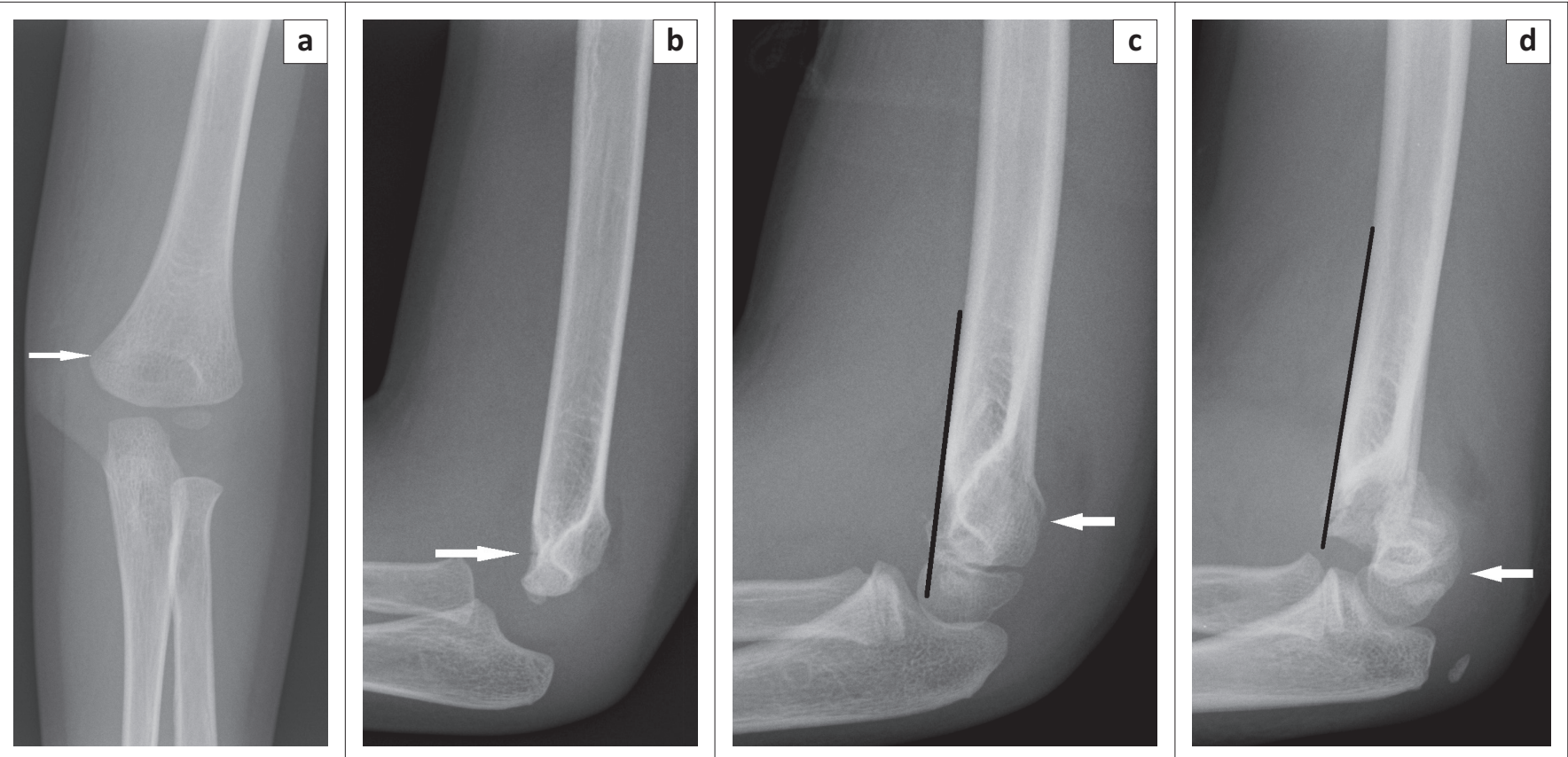

FIGURE 7: Type 1 supracondylar fracture on (a) AP and (b) lateral (arrow) with positive posterior fat pad and intact posterior cortex. Note with the incompletely ossified capitellum that one cannot use the anterior humeral line to assess alignment. (c) Type 2 supracondylar fracture showing posteriorly displaced fragment as evidenced by abnormal anterior humeral line (black line), although fracture is visible, posterior cortex is intact(white arrow) and positive posterior fat pad. (d) Type 3 supracondylar fracture with displaced fragment (arrow), discontinuous anterior humeral line (black line) and posterior fat pad. 
Malunion causes a varus abnormality, the severity of which is measured on the true AP projection by the Baumann angle, which uses radiographically identifiable landmarks to compare the healed with the normal elbow (Figure 8). Although primarily a cosmetic deformity, it may cause pain and late development of posterolateral elbow instability, which can be corrected with a valgus osteotomy.

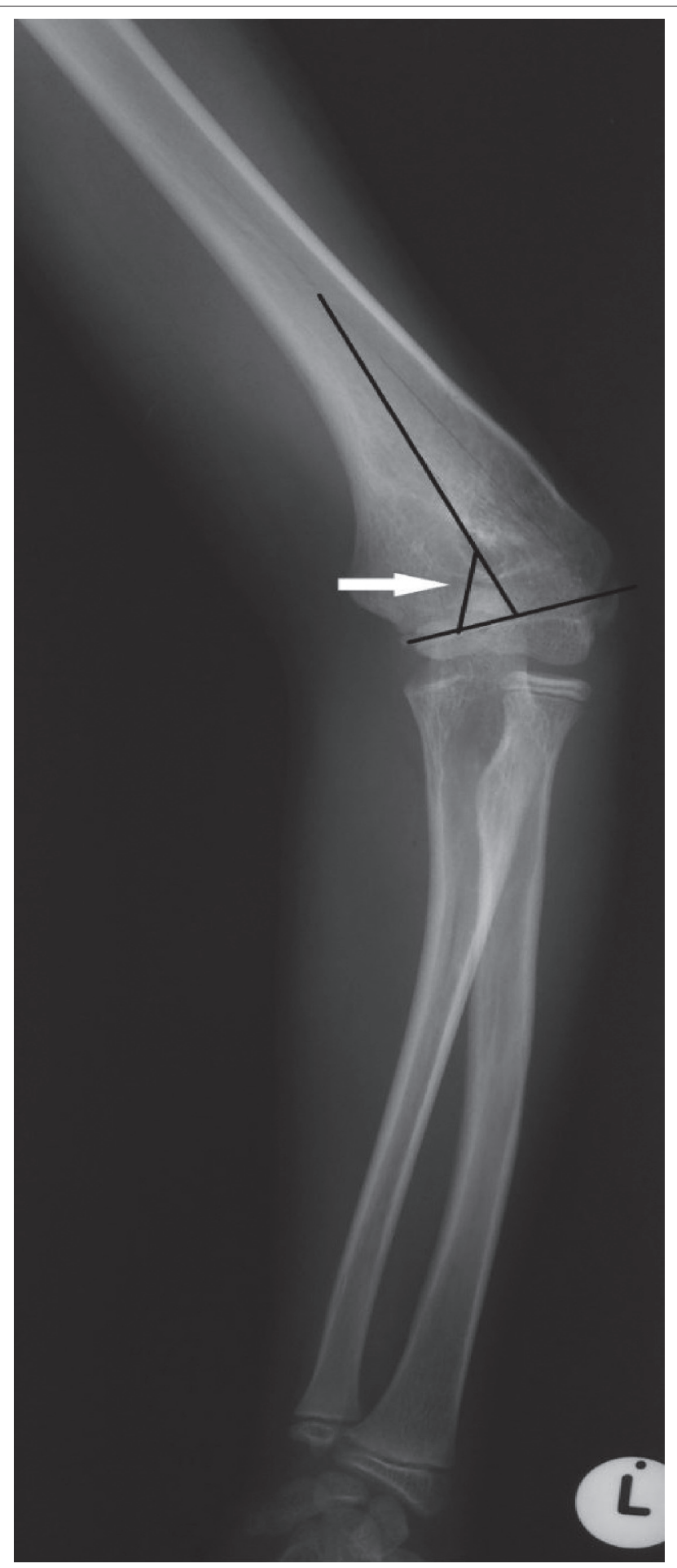

FIGURE 8: Baumann's angle (shown) is formed by the intersection of a line drawn perpendicular to the humeral shaft and a line along the physis of the lateral condyle. A normal Baumann's angle within the paediatric population ranges from $85-89$ degrees. It is important to compare angles between the normal and abnormal side, a difference of more than 5 degrees predicts a possible varus deformity.
Not to be missed look-alike - Non-accidental injury (NAI)
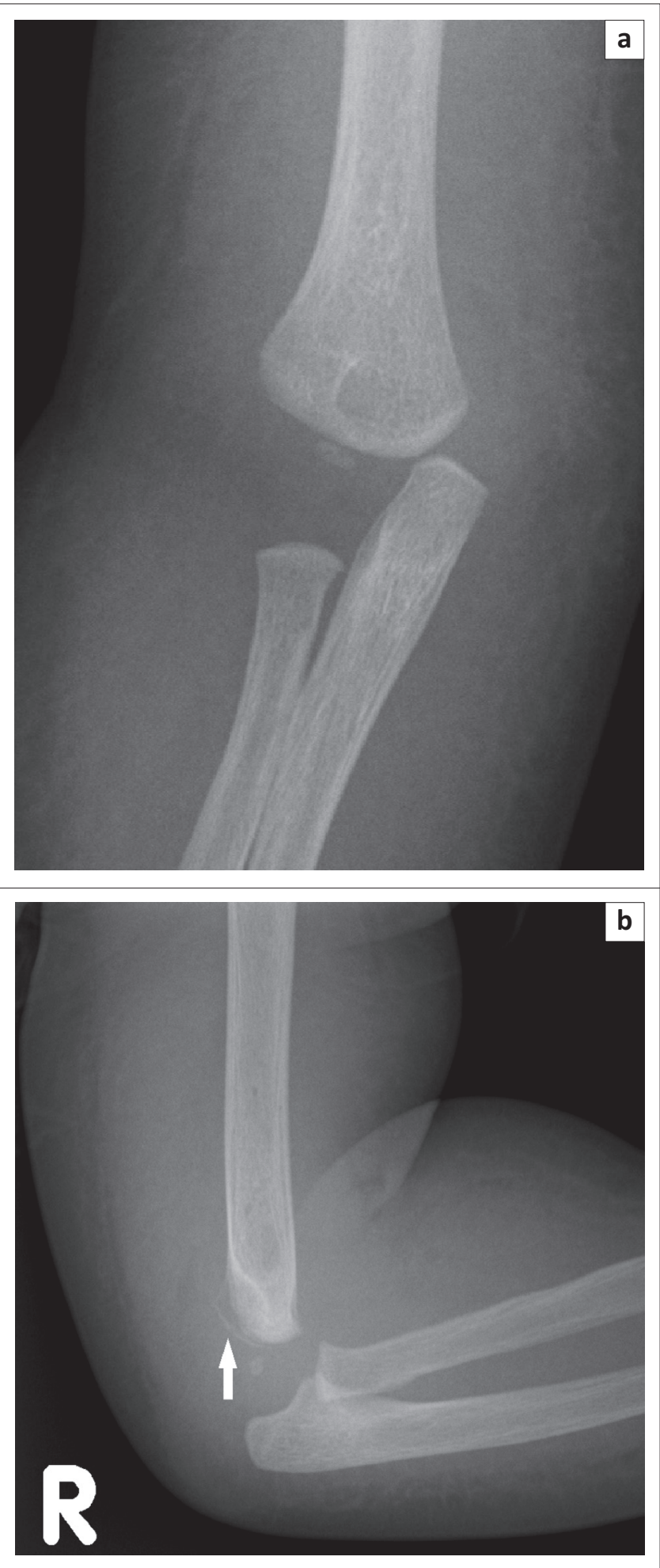

FIGURE 9: (a) AP and (b) Lateral views in a one-month-old with a swollen elbow who died soon after admission. Note the marked soft tissue swelling, the presence of a posterior fat pad and the bucket handle metaphyseal fracture. Multiple additional fractures were identified at post mortem.

- T!PS

- Non-mobile infant.

- History will be suspicious.

- Bucket handle or corner fracture of distal humerus.

- Requires full skeletal survey. 
b) Lateral condyle $10 \%-15 \%$ (Diagram 2)

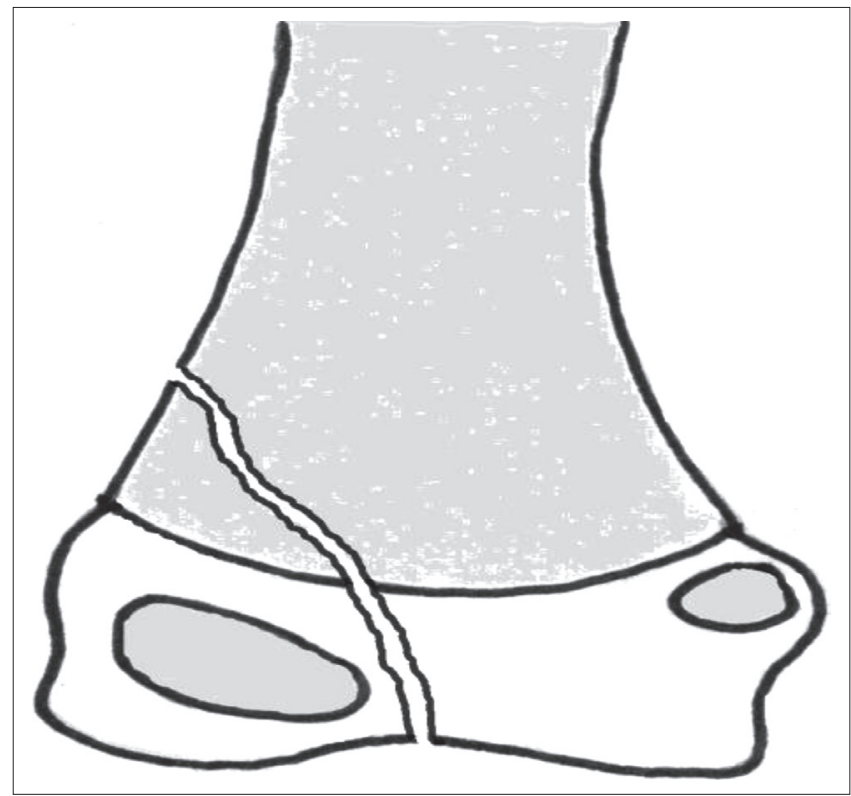

DIAGRAM 2

- T!PS

- Second most common fracture, so look carefully.

- Lateral soft tissue swelling is the clue on AP view.

- Cortical breach is posterior on lateral view.

- Need to document amount of displacement.

- Internal oblique view helpful (Figure 10). c) Medial epicondyle $10 \%$ (Diagram 3)

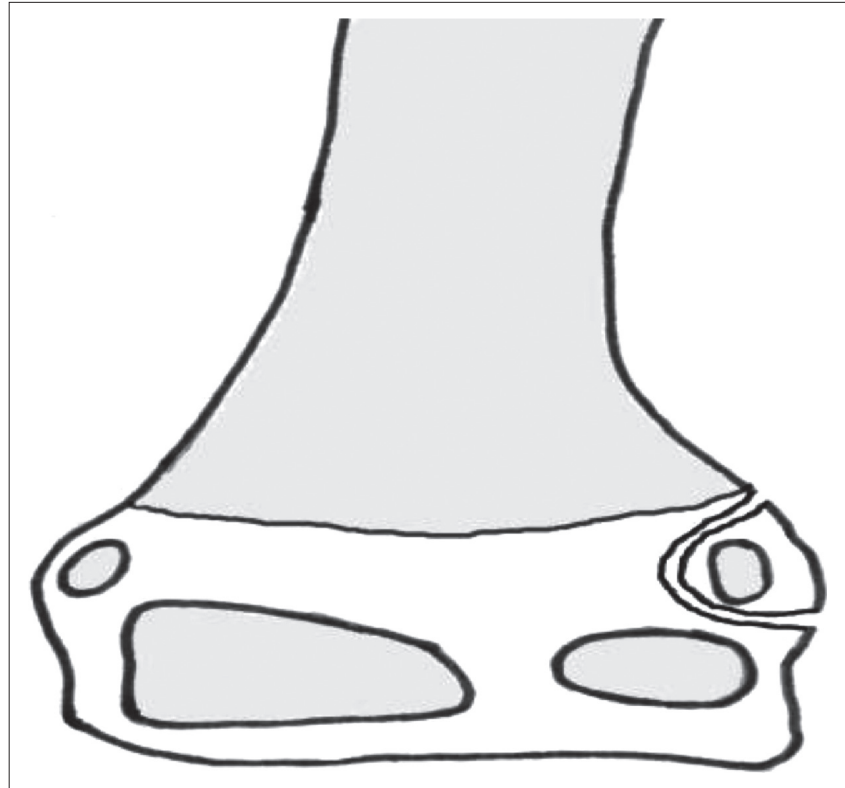

DIAGRAM 3

- T!PS

- Displacement best seen on AP view.

- Look for medial soft tissue swelling.

- Always confirm normal position in a child $>6$ years.

- If no epicondyle seen, look for entrapment in the joint (Figure 11).

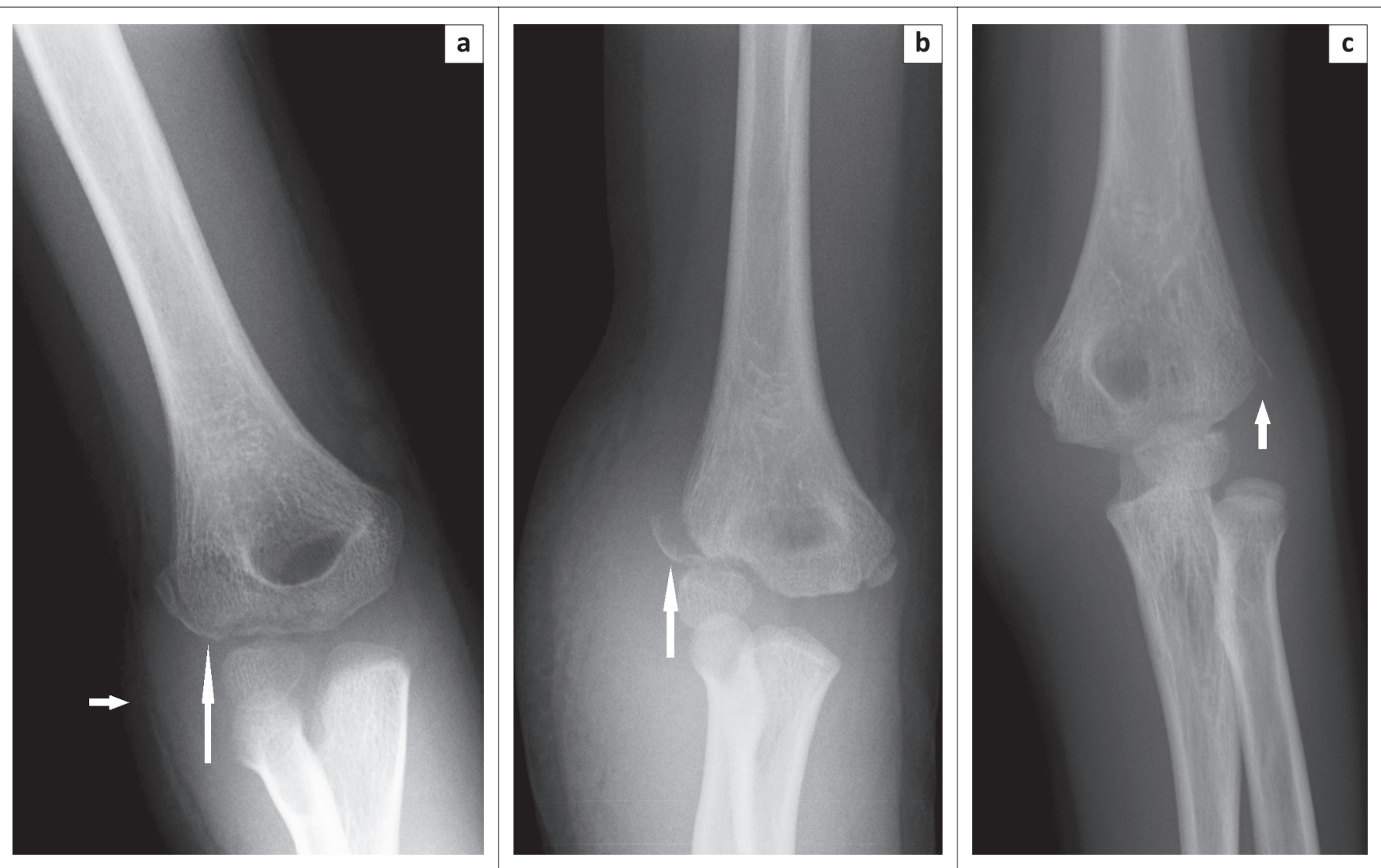

FIGURE 10: (a) Undisplaced right lateral condyle fracture (long arrow). Note lateral soft tissue swelling (short arrow). (b) Displaced right lateral condyle fracture (arrow). (c) Internal oblique showing left lateral condyle fracture that was suspected but not visible on the AP projection. 

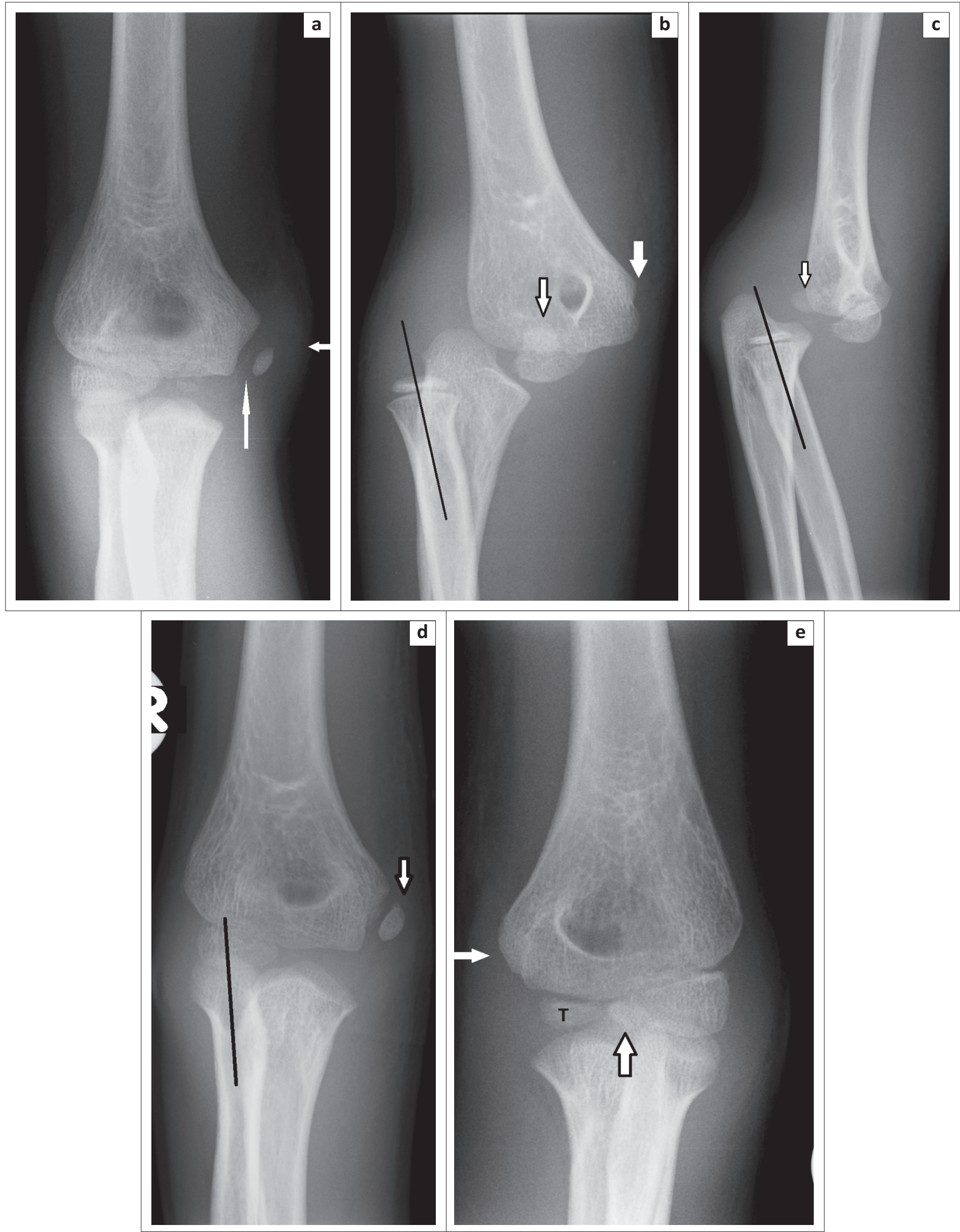

FIGURE 11: (a) Right medial epicondyle fracture (long arrow) with minimal displacement treated conservatively. Note the striking medial soft tissue swelling (short arrow). (b) AP and (c) lateral projections of a six-year-old. The radiocapitellar line is broken (black line), in keeping with dislocation. Medial soft tissue swelling and absence of the normal medial epicondyle (white arrow) in a child of this age should prompt careful evaluation for an entrapped epicondyle within the joint (white and black arrow). (d) Post reduction image of the same child as ( $a$ and b), showing radiocapitellar alignment (black line) and relocated medial epicondyle (black arrow). (e) AP of right elbow in a nine-year-old - the ossification centre of the trochlea is normally positioned (T); the medial epicondyle is not seen (short arrow) as it lies trapped within the joint (white and black arrow). 
d) Medial condyle (<1\%) (Diagram 4)

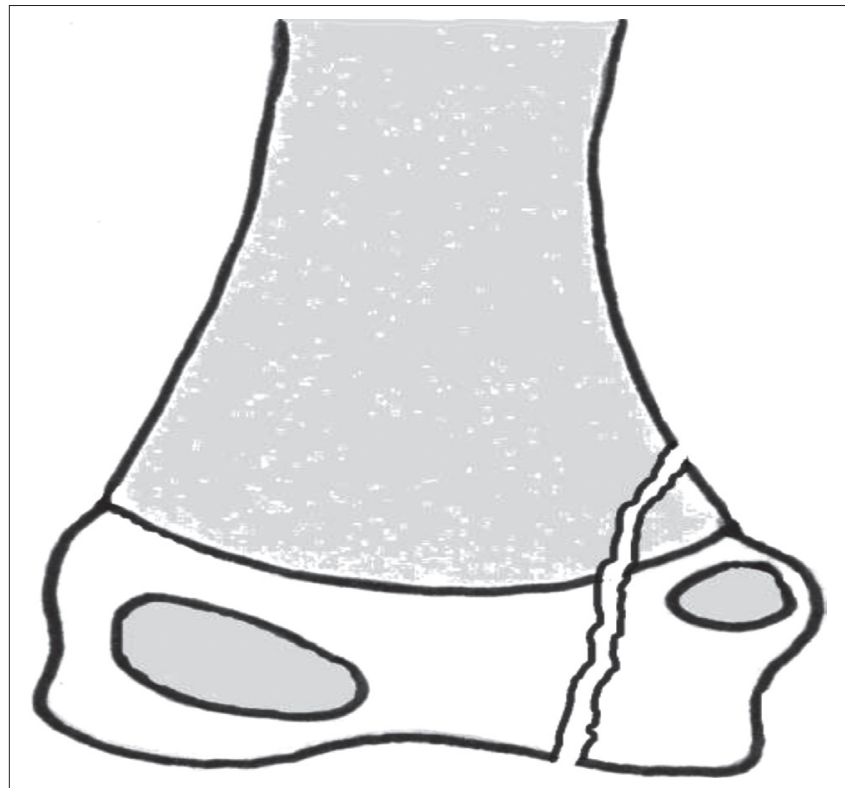

DIAGRAM 4

- T!PS

- Look for medial soft tissue swelling.

- Uncommon.

- Often difficult to differentiate from medial epicondyle fracture.

- May be difficult to see extent; external oblique projection helpful (Figure 12).

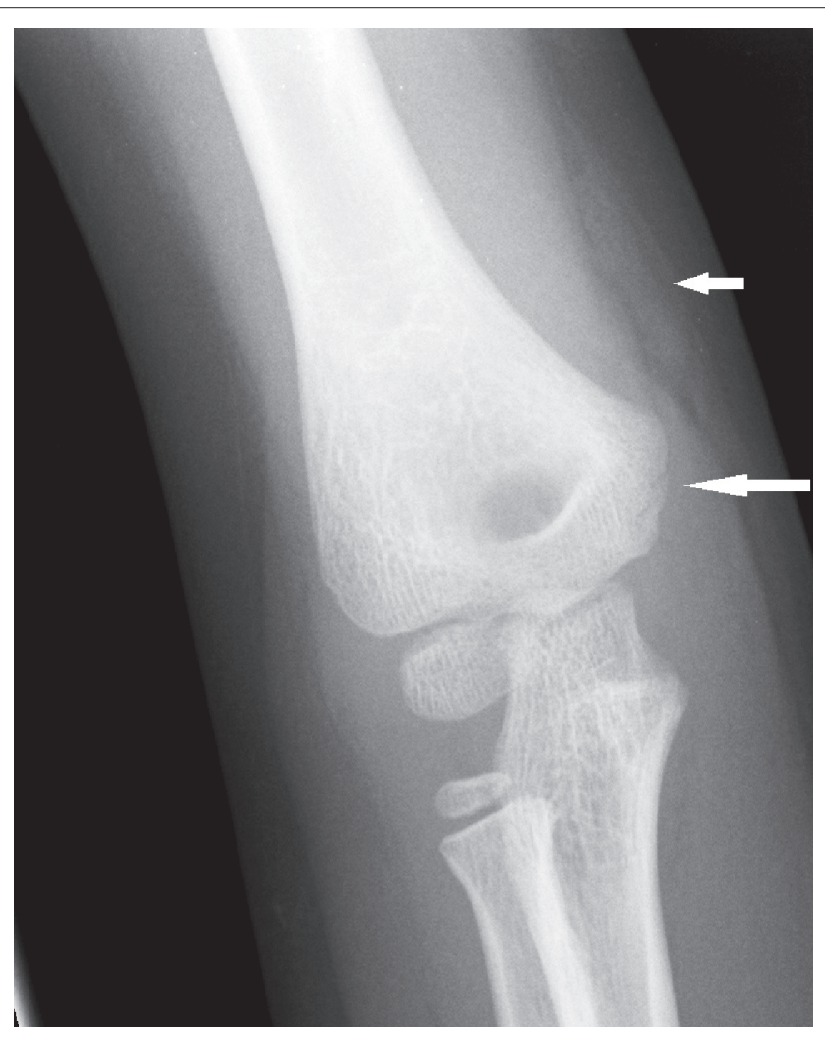

FIGURE 12: Left medial condyle fracture in a 4 year old. Note the medial soft tissue swelling (short arrow) and the subtle fracture line involving the medial condyle (long arrow) e) Lateral epicondyle (<1\%) (Diagram 5)

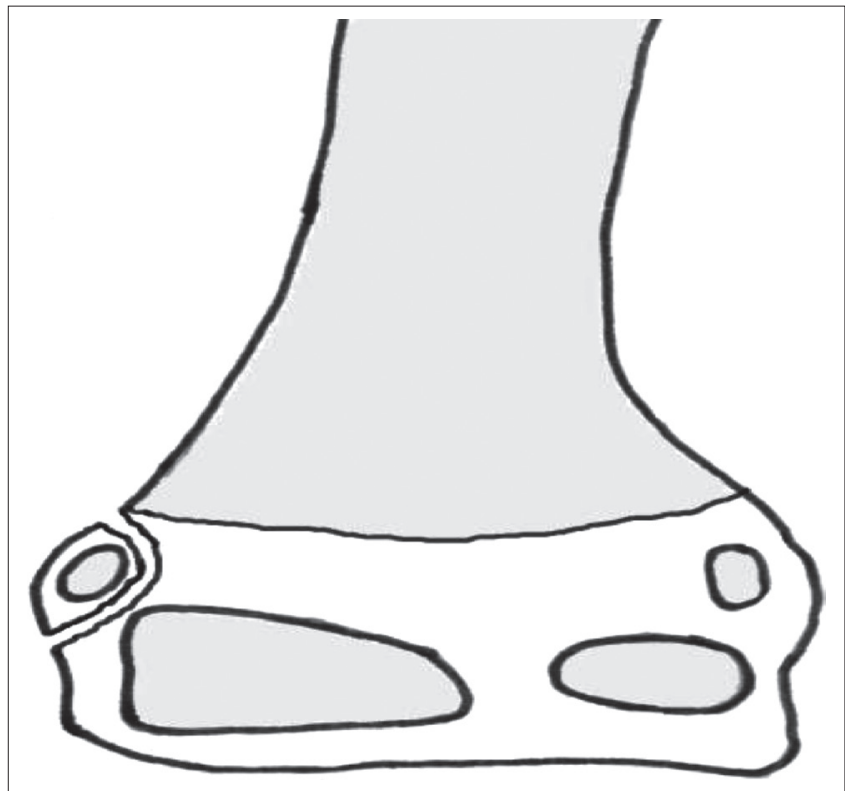

DIAGRAM 5

- T!PS

- Very rare! Make sure you are not looking at a lateral condyle fracture instead.

- Only ossifies after 11 years.

- Lateral soft tissue swelling may be only finding.

- Internal oblique projection may be helpful (Figure 13). ${ }^{16}$

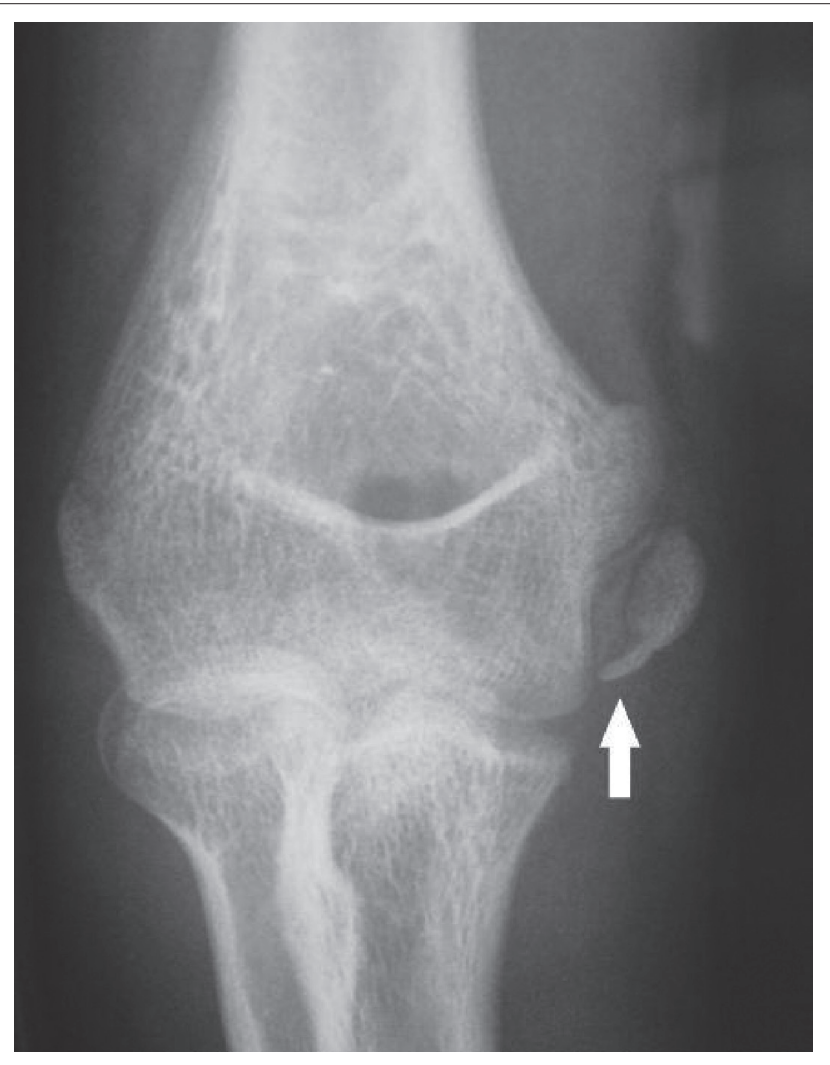

FIGURE 13: A 12-year-old with direct blow to elbow. Note the lateral soft tissue swelling and linear fracture through the lateral epicondyle (arrow). 


\section{f) Intercondylar $<1 \%$ (Diagram 6)}

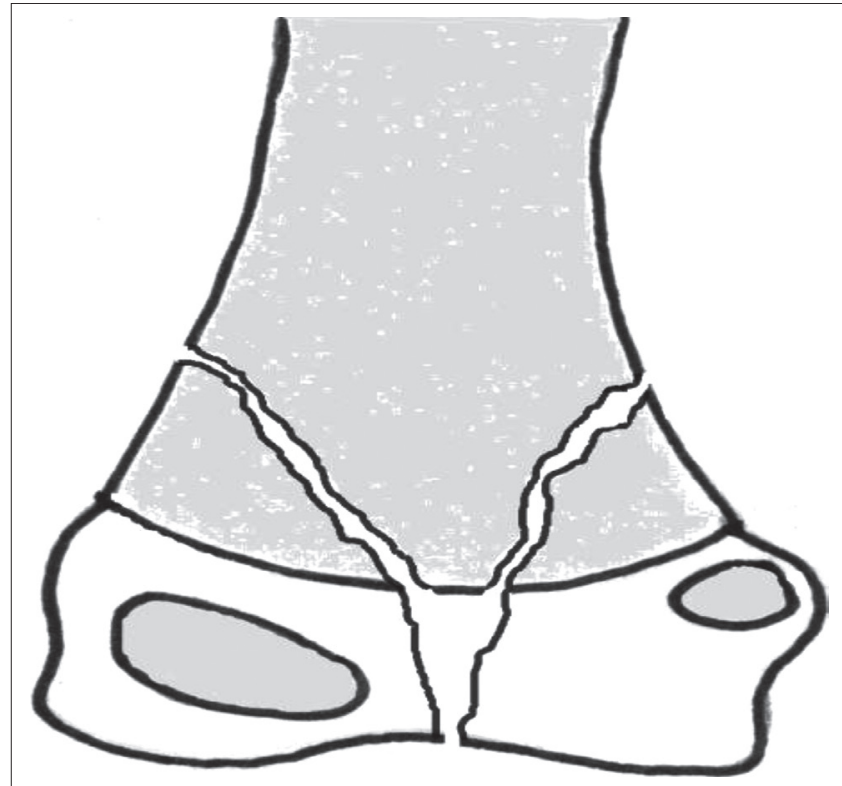

DIAGRAM 6

- T!PS

- Often misdiagnosed as supracondylar fracture.

- Look for sagittal component that splits medial and lateral condyles and extends to articular surface (Figure 14).

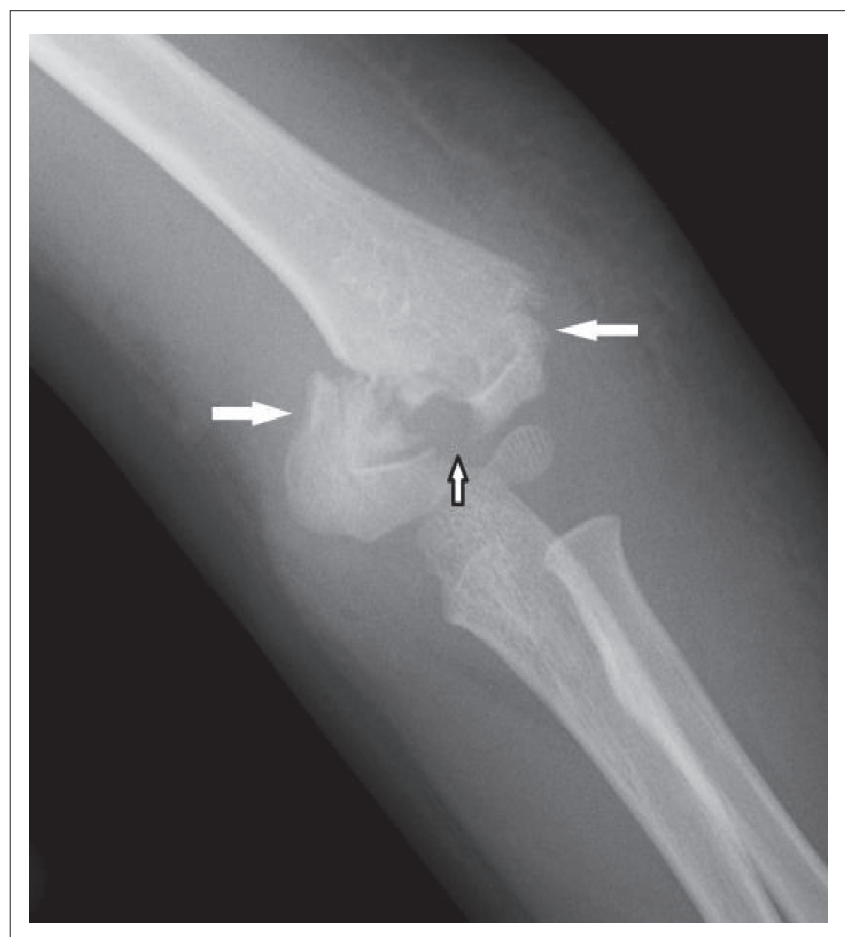

FIGURE 14: Intercondylar fracture that extends sagittally to the articular surface (black and white arrow) splitting the medial and lateral condyles (white arrows).

g) Transcondylar (transphyseal) <1\% (Diagram 7)

- T!PS

- Mimics posterior dislocation.

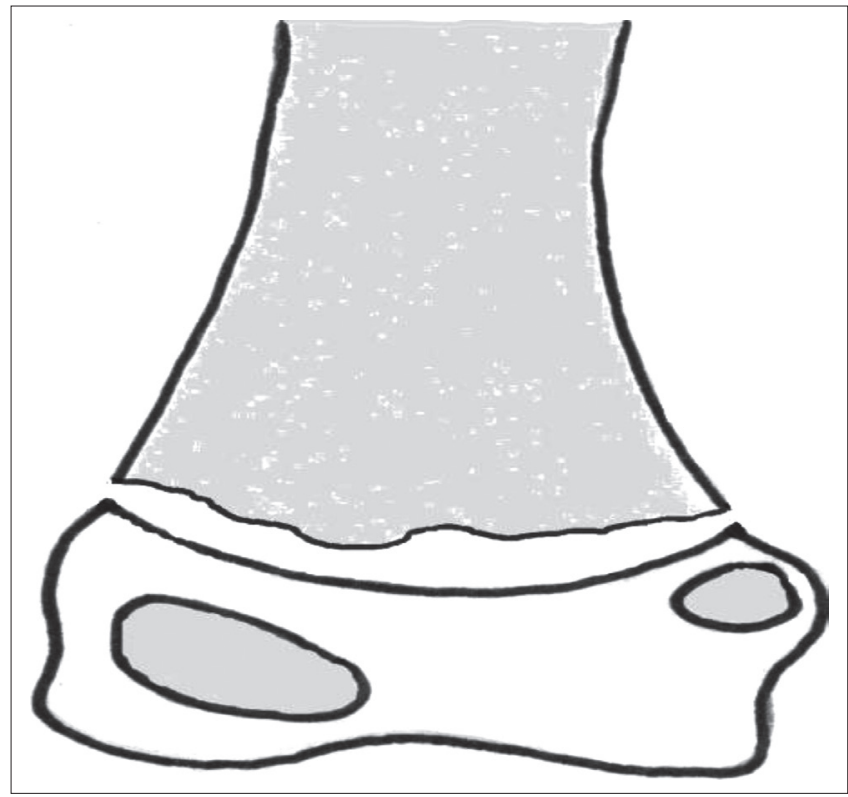

DIAGRAM 7

- Radius and ulna not aligned with humerus on lateral.

- NB: Radiocapitellar line is maintained; cf. dislocation (Figure 15).
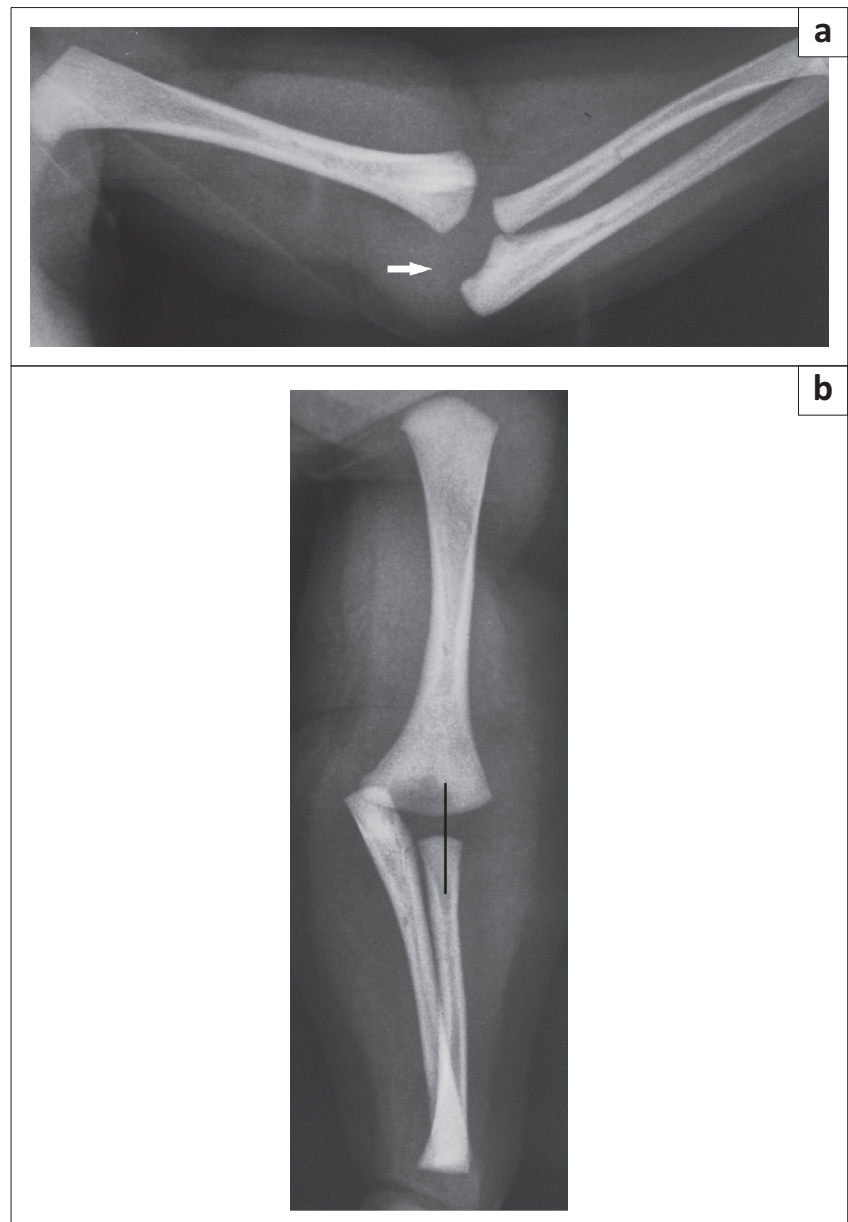

FIGURE 15: (a) Lateral projection in neonate with a swollen elbow shows marked soft tissue swelling. Ulna and radius appear posteromedially displaced (arrow). (b) AP projection with line drawn along radial shaft that intersects with expected position of the capitellum excluding dislocation and implying a transcondylar fracture. 
TABLE 2: Summary of paediatric elbow fracture/dislocations. ${ }^{1,15}$

\begin{tabular}{|c|c|c|c|c|c|c|}
\hline Fracture type & Prevalence & Ages (yrs) & Mechanism of injury & Classification & Management & Tips and pitfalls \\
\hline \multirow[t]{5}{*}{ Supracondylar } & \multirow[t]{5}{*}{$50 \%-70 \%$} & \multirow[t]{5}{*}{$3-10$} & \multirow{5}{*}{$\begin{array}{l}\text { Fall on an outstretched } \\
\text { hand - hyperextension } \\
(95 \%)\end{array}$} & According to Gartland: & Type 1 Splint/cast & Best identified on lateral. \\
\hline & & & & Type 1 Non-displaced & \multirow{4}{*}{$\begin{array}{l}\text { Type } 2 / 3 \text { Closed } \\
\text { reduction and } \\
\text { percutaneous pinning }\end{array}$} & $25 \%$ are subtle, common \\
\hline & & & & Type 2 Distal fragment posteriorly & & cause of occult fracture. \\
\hline & & & & $\begin{array}{l}\text { displaced, posterior cortex retained, } \\
\text { acts as hinge }\end{array}$ & & $\begin{array}{l}\text { Associated with ipsilateral } \\
\text { distal radial fracture. }\end{array}$ \\
\hline & & & & $\begin{array}{l}\text { Type } 3 \text { Circumferential cortical breach, } \\
\text { displaced fragment. }\end{array}$ & & $\begin{array}{l}\text { Type } 3 \text { malunion } \\
\text { and neurovascular } \\
\text { complications }\end{array}$ \\
\hline \multirow[t]{6}{*}{ Lateral condyle } & \multirow[t]{6}{*}{$10 \%-15 \%$} & \multirow[t]{6}{*}{$6-10$} & \multirow{6}{*}{$\begin{array}{l}\text { Varus force applied to } \\
\text { extended elbow while } \\
\text { forearm supinated. }\end{array}$} & $\begin{array}{l}\text { Type } 1 \text { Incomplete; fracture does not } \\
\text { traverse epiphysis. Non =-displaced }\end{array}$ & $\begin{array}{l}\text { Non-displaced - Posterior } \\
\text { splinting }\end{array}$ & $\begin{array}{l}\text { Fracture line usually barely } \\
\text { visible. }\end{array}$ \\
\hline & & & & Type 2 Complete but not displaced & \multirow{5}{*}{$\begin{array}{l}\text { Displaced }>2 \mathrm{~mm} \\
\text { Open reduction and } \\
\text { percutaneous pinning }\end{array}$} & Since fracture is through \\
\hline & & & & $\begin{array}{l}\text { Type } 3 \text { Complete with displaced/ } \\
\text { rotated fragment. }\end{array}$ & & $\begin{array}{l}\text { cartilage, it is difficult to } \\
\text { know extent (MRI can } \\
\text { assist). }\end{array}$ \\
\hline & & & & \multirow{3}{*}{ Can be Salter-Harris Type 2, 3 or 4} & & $\begin{array}{l}\text { Internal oblique view } \\
\text { helpful. }\end{array}$ \\
\hline & & & & & & $\begin{array}{l}\text { NB to document } \\
\text { displacement. }\end{array}$ \\
\hline & & & & & & $\begin{array}{l}\text { Suspected non-displaced } \\
\text { fractures - do serial } \\
\text { radiographs to see callus } \\
\text { formation }\end{array}$ \\
\hline \multirow[t]{2}{*}{ Medial condyle } & \multirow[t]{2}{*}{$<1 \%$} & \multirow[t]{2}{*}{$8-14$} & \multirow[t]{2}{*}{$\begin{array}{l}\text { Fall onto flexed elbow } \\
\text { or outstretched arm }\end{array}$} & \multirow[t]{2}{*}{$\begin{array}{l}\text { Based on location and displacement - } \\
\text { usually Salter-Harris Type } 4\end{array}$} & \multirow{2}{*}{$\begin{array}{l}\text { Undisplaced - conservative. } \\
\text { Displaced or unstable - pinning }\end{array}$} & $\begin{array}{l}\text { Often confused with medial } \\
\text { epicondyle fracture. }\end{array}$ \\
\hline & & & & & & $\begin{array}{l}\text { Not related to dislocation. } \\
\text { Usually unstable }\end{array}$ \\
\hline \multirow[t]{3}{*}{ Lateral epicondyle } & \multirow[t]{3}{*}{ Rare } & \multirow[t]{3}{*}{$9-15$} & \multirow{3}{*}{$\begin{array}{l}\text { Owing to traction on } \\
\text { extensor mechanism. } \\
\text { In older child, due to } \\
\text { direct blow }\end{array}$} & & \multirow{3}{*}{$\begin{array}{l}\text { Undisplaced-conservative. } \\
\text { Displaced-fixation and } \\
\text { immobilisation }\end{array}$} & $\begin{array}{l}\text { Usually seen in setting of } \\
\text { other injuries. }\end{array}$ \\
\hline & & & & & & $\begin{array}{l}\text { Comment on displacement } \\
\text { and rotation. }\end{array}$ \\
\hline & & & & & & $\begin{array}{l}\text { Does not contribute to } \\
\text { growth discrepancy }\end{array}$ \\
\hline \multirow[t]{5}{*}{ Medial epicondyle } & \multirow[t]{5}{*}{$10 \%$} & \multirow[t]{5}{*}{$7-15$} & \multirow{2}{*}{$\begin{array}{l}\text { Valgus stress avulsing } \\
\text { epicondyle by forearm } \\
\text { flexor pronator tendons. }\end{array}$} & \multirow[t]{5}{*}{ Salter-Harris Type 3 or 4} & $<5 \mathrm{~mm}$ displacement - conservative & Older children than SC/LC. \\
\hline & & & & & $>5$ mm - institutional specific. & $\begin{array}{l}\text { Entrapment best seen on } \\
\text { lateral. }\end{array}$ \\
\hline & & & $\begin{array}{l}\text { Can be fractured by } \\
\text { direct force }\end{array}$ & & Incarcerated fragments - & Usually no joint effusion. \\
\hline & & & & & $\begin{array}{l}\text { open reduction and screw fixation } \\
\text { when closed reduction fails to } \\
\text { extrude fragment from joint }\end{array}$ & $\begin{array}{l}50 \% \text { associated with } \\
\text { posterior elbow } \\
\text { dislocations. }\end{array}$ \\
\hline & & & & & & $\begin{array}{l}\text { If equivocal or unossified, } \\
\text { needs evaluation with MRI }\end{array}$ \\
\hline $\begin{array}{l}\text { Intercondylar/ } \\
\text { T-condylar/Y-condylar }\end{array}$ & $<1 \%$ & 9-13 & $\begin{array}{l}\text { Flexion or extension } \\
\text { injury }\end{array}$ & & Operative & $\begin{array}{l}\text { Uncommon prior to skeletal } \\
\text { maturity. }\end{array}$ \\
\hline & & & & & & $\begin{array}{l}\text { Often misdiagnosed as } \\
\text { supracondylar, lateral/ } \\
\text { medial condylar fractures }\end{array}$ \\
\hline $\begin{array}{l}\text { Transphyseal/ } \\
\text { transcondylar }\end{array}$ & $<1 \%$ & $<2$ & $\begin{array}{l}\text { Birth trauma, fall on } \\
\text { outstretched hand, }\end{array}$ & Salter-Harris Type 1 & Conservative management & $\begin{array}{l}\text { Can be misdiagnosed as } \\
\text { posteromedial dislocation. }\end{array}$ \\
\hline & & & & & & $\begin{array}{l}\text { NB: Radiocapitellar } \\
\text { alignment is normal. }\end{array}$ \\
\hline & & & & & & $\begin{array}{l}\text { Has high index of suspicion } \\
\text { for NAI }\end{array}$ \\
\hline Olecranon & $4 \%-7 \%$ & $10-18$ & $\begin{array}{l}\text { Fall on outstretched } \\
\text { hand or direct trauma }\end{array}$ & $\begin{array}{l}\text { Usually Salter-Harris Type } 2 . \\
\text { Salter-Harris Type } 1 \text { can occur }\end{array}$ & $\begin{array}{l}\text { Non- or minimally displaced } \\
\text { (majority) - cast immobilisation }\end{array}$ & $\begin{array}{l}\text { Ossifies at } 10 \mathrm{y} \text { and fused } \\
\text { by } 18 \mathrm{y} \text {. }\end{array}$ \\
\hline & & & & but uncommon & $\begin{array}{l}\text { Displaced - screw fixation/tension } \\
\text { band constructs }\end{array}$ & $\begin{array}{l}\text { Bipartite/eccentric, } \\
\text { irregularly or diffusely } \\
\text { sclerotic olecranon } \\
\text { ossification centre - do } \\
\text { comparison lateral view if } \\
\text { unsure. }\end{array}$ \\
\hline & & & & & & $\begin{array}{l}\text { NB: } 14-77 \% \text { associated } \\
\text { radial neck fracture, lateral } \\
\text { or medial condylar fracture } \\
\text { or radial head dislocation }\end{array}$ \\
\hline Proximalradius (head & $4 \%-5 \%$ & & Fall on outstretched & O’Brien Classification & & Oblique views may disclose \\
\hline & & & & $1<30$ degrees angulation. & & \\
\hline & & & & 2 angulated $30-60$ degrees. & & \\
\hline & & & & $3>60$ degrees & & \\
\hline Elbow dislocation & $3 \%-5 \%$ & $12-13$ & $\begin{array}{l}\text { Fall on outstretched } \\
\text { hand, forearm }\end{array}$ & & $\begin{array}{l}\text { Uncomplicated posterolateral } \\
\text { dislocation - closed reduction. }\end{array}$ & $\begin{array}{l}\text { Posterior dislocation of } \\
\text { radius and ulna with typical }\end{array}$ \\
\hline & & & $\begin{array}{l}\text { supinated, elbow fully } \\
\text { extended/partially }\end{array}$ & & $\begin{array}{l}\text { Entrapped medial epicondylar } \\
\text { fragment - open surgical reduction }\end{array}$ & $\begin{array}{l}\text { lateral displacement is } \\
\text { most common }\end{array}$ \\
\hline & & & & & may be necessary & $\begin{array}{l}\text { Associated fracture in } 64 \% \\
\text { of posterior dislocations } \\
\text { (medial epicondyle/ } \\
\text { condyles/radial neck) }\end{array}$ \\
\hline
\end{tabular}




\section{Step 6 - Look for radial and/or ulnar fractures.}

a) Olecranon fracture $4 \%-7 \%$

- T!PS

- Normal ossification centre may be fragmented.

- Look for soft tissue swelling.

- Look for associated fractures of medial and lateral condyles and radial neck.

- Look for elbow dislocation (Figure 16).

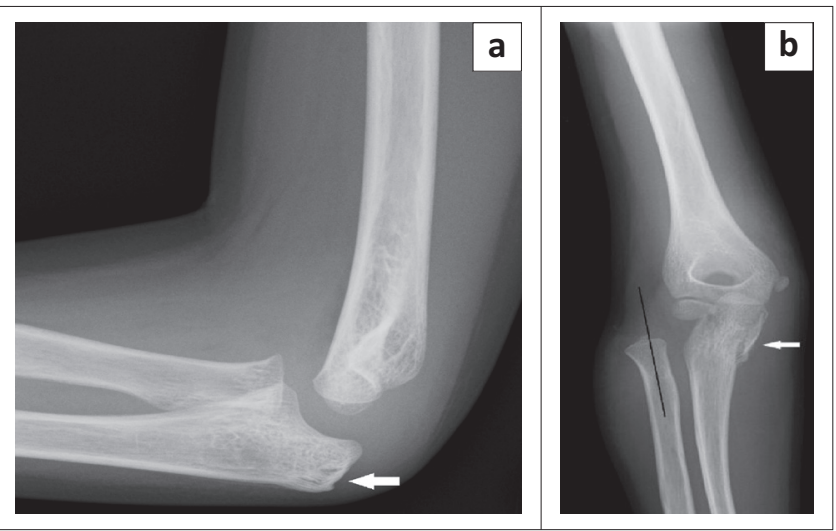

FIGURE 16: (a) Soft tissue swelling overlying the olecranon, which has a subtle undisplaced fracture (arrow). (b) Olecranon fracture (arrow) in the setting of dislocation. Note the interrupted radiocapitellar line (black line).

\section{b) Proximal radial fracture $4 \%-5 \%$}

- $\quad$ T!PS

- Neck more common than head.

- Posterior fat pad is a clue.

- Oblique views are helpful.

- In radial dislocation, look for associated ulna fracture (Figure 17).
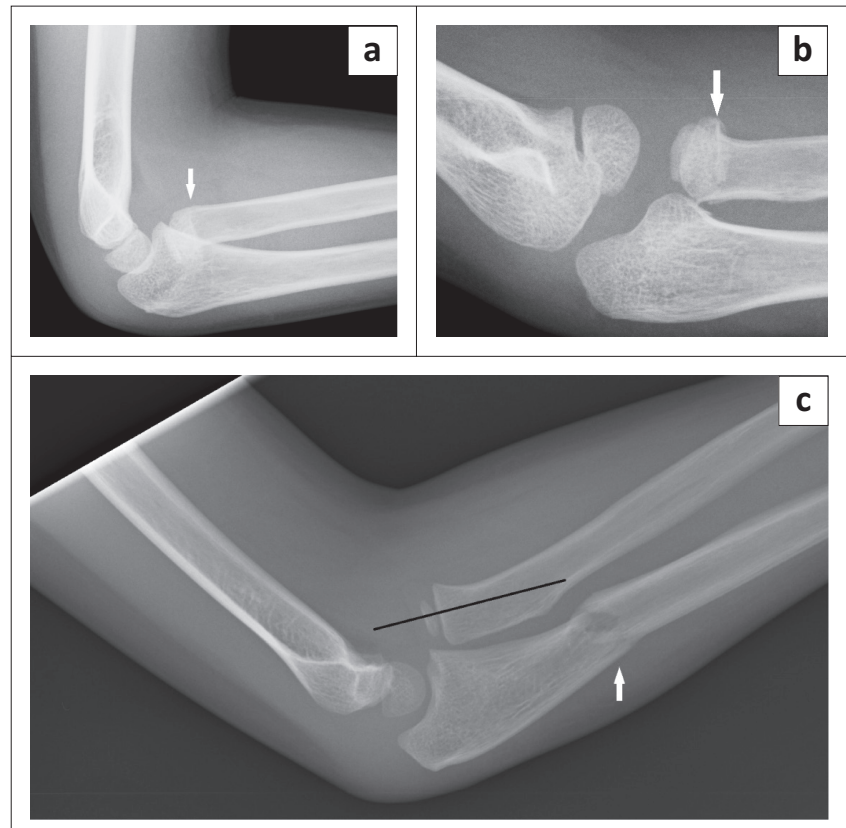

FIGURE 17: (a) Lateral and (b) oblique images of a four-year-old with a radial neck fracture (arrows). (c) A five-year-old with radial dislocation (note interrupted radiocapitellar line) and proximal ulnar fracture.

\section{Conclusion}

A systematic approach to paediatric elbow reporting in the post-traumatic setting is an asset for everyday radiological practice. Knowledge of the developmental anatomy of the elbow underscored by an understanding of common mimics and pitfalls is fundamental.

\section{Acknowledgements Competing interests}

The authors declare that they have no financial or personal relationships which may have inappropriately influenced them in writing this article.

\section{Author's contribution}

T.K. (Red Cross War Memorial Children's Hospital) - Written text and legends. Graphics. H.M. (Red Cross War Memorial Children's Hospital) - Diagrams, figures, data collection. S.M. (Red Cross War Memorial Children's Hospital) - Fact checking, editing, figures and legends.

\section{References}

1. Iyer RS, Thapa MM, Khanna PC, Chew FS. Pediatric bone imaging: Imaging elbow trauma in children - A review of acute and chronic injuries. AJR. 2012;198:10531068. PMID: 22528894, http://dx.doi.org/10.2214/AJR.10.7314

2. Song $\mathrm{KS}$, Kang $\mathrm{CH}$, Min BW, Bae $\mathrm{KC}$, Cho $\mathrm{CH}$. Internal oblique radiographs for diagnosis of nondisplaced or minimally displaced lateral condylar fractures of the humerus in children. J Bone Joint Surg Am. 2007;89(1):58-63. PMID: 17200311, http://dx.doi.org/10.2106/JBJS.E.01387

3. Johnson KL, Bache E. In Pediatric skeletal trauma - Techniques and applications. Berlin Heidelberg New York: Springer; 2008.

4. Chacon D, Kissoon N, Brown T, Galpin R. Use of comparison radiographs in the diagnosis of traumatic injuries of the elbow. Ann Emerg Med. 1992;21 (8):895-899. PMID: 1497152, http://dx.doi.org/10.1016/S0196-0644(05)82923-3

5. Kissoon N, Galpin R, Gayle M, Chacon D, Brown T. Evaluation of the role of comparison radiographs in the diagnosis of traumatic elbow injuries. J Pediatr Orthop. 1995;15(4):449-453. PMID: 7560032.

6. Rickett $A B$, Finlay $D B$. An audit of comparative views in elbow trauma in children. Br J Radiol. 1993;66(782):123-125. PMID: 8457824, http://dx.doi. org/10.1259/0007-1285-66-782-123

7. Dowling $\mathrm{S}$, Farion $\mathrm{K}$, Clifford $\mathrm{T}$. Comparison views to diagnose elbow injuries in children: A survey of Canadian non-pediatric emergency physicians. Can J Emerg Med. 2005;7(4):237-240. PMID: 17355679.

8. Goswami GK. The fat pad sign. Radiology. 2002;222:419-420. http://dx.doi. org/10.1148/radiol.2222000365

9. Donnelly LF, Klostermeier TT, Klosterman LA. Traumatic elbow effusions in pediatric patients: Are occult fractures the rule? AJR. 1998;171:243-245. PMID: 9648797 http://dx.doi.org/10.2214/ajr.171.1.9648797

10. Major NM, Crawford ST. Elbow effusions in trauma in adults and children: Is there an occult fracture? AJR. 2002;178:413-418. PMID: 11804906.

11. Chapman V, Grottkau B, Albright M, Elaini A, Halpern E, Jaramillo D. MDCT of the elbow in pediatric patients with posttraumatic elbow effusion. AJR 2006;187:812-817. PMID: 16928950, http://dx.doi.org/10.2214/AJR.05.0606

12. Herman MJ, Boardman MJ, Hoover JR, Chafetz RS. Relationship of the anterior humeral line to the capitellar ossific nucleus: Variability with age. J Bone Joint Surg Am. 2009;91(9):2188-2193. PMID: 19723996, http://dx.doi.org/10.2106/ JBJS.H.01316

13. Patel B, Reed M, Patel S. Gender-specific pattern differences of the ossification centres in the pediatric elbow. Pediatr Radiol. 2009·39:226-231. PMID: 19125245, http://dx.doi.org/10.1007/s00247-008-1078-4

14. Cheng JC, Wing-Man K, Shen WY, et al. A new look at the sequential development of elbow-ossification centres in children. J Pediatr Orthop. 1998;18(2):161-167. PMID: 9531396.

15. Beaty JH, Kasser JR. Rockwood and Wilkins' fractures in children. 6th ed. Lippincott Williams \& Wilkins; 2006. 